\title{
Kampania smoleńska Władysława IV (1634) w twórczości Samuela ze Skrzypny Twardowskiego
}

Michał Kuran 


\section{Michał Kuran}

\section{Kampania smoleńska Władysława IV (1634) w twórczości Samuela ze Skrzypny Twardowskiego}

$\mathrm{D}$ wa teksty, które Samuel Twardowski poświęcił w całości wydarzeniom smoleńskim: Szczęsliw a moskiewska ekspedycyja... ${ }^{1}$ oraz V „punkt” WTadystawa IV króla polskiego i szwedzkiego ${ }^{2}$, wydają się interesujące po pierwsze ze względu na ich wartości artystyczne, po wtóre zaś dlatego, że pozwalają obserwować zmieniające się spojrzenie autora na wydarzenia: przedstawiane najpierw na gorąco, a później już z pewnej czasowej perspektywy. Za każdym razem poeta posługuje się adekwatną do sytuacji formą wypowiedzi. Kieruje też komunikat do innego odbiorcy i stawia w centrum zainteresowania innych bohaterów.

Twardowski odniósł znaczący sukces literacki opublikowaną w 1633 roku, dedykowaną księciu Januszowi Wiśniowieckiemu Przeważna legacyją..., gdzie przedstawił dzieje poselstwa Krzysztofa Zbaraskiego do Turcji. W Ekspedycyi... (która wyszła spod pras jeszcze w drugim roku kampanii) sięgnął po temat ciągle żywy w pamięci społecznej, by jednak utrwalić już nie dzieje któregoś z niewątpliwie zasłużonych dla Rzeczypospolitej książąt, lecz upamiętnić czyny lubianego i otaczanego wielkim szacunkiem przez szlachtę, nowo wybranego króla Władysława IV, który, będąc jeszcze królewiczem, zdążył zasłynąć w całej Europie jako obrońca chrześcijaństwa podczas kampanii chocimskiej 1621 roku.

\footnotetext{
1 S. Twardowski, Szczęstiua moskiewska ekspedycyja Najaśniejszego Wadystawa IV króla polskiego i szu'edzkiego...piórem ojczystym przez Sammela z Skrzypnej Tivardowskiego opisana, roku 1634, w Warszawic, u wdowy Jana Rossowskicgo, 1634 (dalcj: Ekspedycyja...; w nawiasach numeracja wersów). Utwór składa siç z 16 picśni różnej objętości (od 16 do 100 w., łącznic 1152 w.). Poszczcgólne wicrsze pisane są odmiennymi formami stroficznymi, od klasycznych: czterowcrsu, oktawy i wiersza heroicznego, po bardzicj wyszukane: dwuwers $12+7$, czterowiersz $6+10+10+6$ czy czterowiersz $12+6+6+12$. Autor stosuje też różne metra: od 6 do 13-zgłoskowca.

2 Idem, Wadysław IV król polski i szwedzki, w Lesznic, u Danicla Vetterusa, roku 1649 (dalcj: Waadyslaw IV; w nawiasach paginacja). Utwór, dedykowany Janowi Kazimicrzowi, bratu i następcy Władysława IV, w piçciu „punktach" (czçściach); w ostatnim miçdzy innymi przcbieg wyprawy moskicwskicj z 1634 roku. Rclacja liczy 1906 w. 13-zgłoskowych; w dalszych 500 omówienie wypraw przeciw Rzeczypospolitej, tj. turecko-tatarskicj Abazego baszy, cesarza tureckiego Amurata, dalcj pertraktacji z królcm Szwecji w sprawic Prus.
} 
Wiedząc, że wydarzenia, które przedstawiał, są powszechnie znane tak wśród szlachty, jak i na dworze królewskim, autor sięgnął po pierwsze do wyszukanych form poetyckich, by uzyskać jak najlepszy efekt artystyczny, po drugie operował znaczącymi skrótami myślowymi. Utwór bowiem poza walorami literackimi ma charakter tekstu użytkowego, pisanego „na gorąco”, adresowanego do uczestników i świadków wydarzeń. Celem Twardowskiego było uczczenie odwagi i determinacji sprawnego dowódcy — króla Władysława, ale przede wszystkim wysiłku zbrojnego społeczności szlacheckiej. Świadczą o tym przywoływane nieustannie nazwiska walczących dowódców oraz bohaterów, którzy wykazali się szczególną bitnością.

Po latach Twardowski powrócił do raz już opisanych wypadków w eposie historycznym poświęconym dziejom władcy. Wydarzenia przedstawil jednak nieco dokładniej niż w Ekspedycyi.

Celem obecnej analizy (z kontekstowymi odwołaniami do wiersza Jakub Wojewódzki pod Smoleńskiem zabit oraz poematu biograficznego Ksiqż̨ Wiśniowiecki Janusz...) będzie porównanie obu tekstów ze względu na konfrontację wypowiedzi poetyckich z prawdą historyczną (na podstawie niezbędnych źródeł, zwłaszcza wykorzystanych przez poetę), konstrukcję bohatera i świata przedstawionego ( $w$ tym batalistyki), wzajemne relacje obu utworów i cel dwukrotnego opisania tej samej wojny, zmianę postrzegania zdarzeń wraz z upływem czasu, modyfikacje tekstów związane ze zmianą adresata - pierwszego odbiorcy wypowiedzi, a wreszcie zapożyczenia stylistyczne z Ekspedycyi we Wtadystawie IV.

\section{Materiały źródłowe do kampanii smoleńskiej}

Wojna smoleńska z lat 1632-1634 należy do wydarzeń historycznych zapomnianych przez współczesnych badaczy dziejów. $O$ ile taki stan rzeczy można tłumaczyć działaniami cenzury w okresie PRL-u, o tyle brak publikacji z ostatniego dziesięciolecia należy uznać za istotne zaniedbanie ${ }^{3}$.

Cieszyła się ona natomiast niesłabnącym zainteresowaniem zarówno $\mathrm{w}$ drugiej połowie XIX wieku, jak też przed II wojną światową, o czym świadczą przede wszystkim prace Wladysława Godziszewskiego oraz Wacława Lipińskiego, który szczegółowo przedstawił przebieg działań militarnych w cyklu monograficzych artykułów ${ }^{4}$, korzystając z polskich i rosyjskich diariuszy, a także korespondencji moskiewskiego dowódcy Michała Borysowicza Szeina z carem Michałem Fiodorowiczem Romanowem. Wyniki badań archiwalnych przeprowadzonych przez Godziszewskie-

${ }^{3}$ O kampanii smoleńskiej wspomina ogólnie w najnowszcj biografii Władysława IV Wazy (Wrocław 1995) jedynie Henryk Wisner.

4 Zob. W. Godziszewski, Polska a Moskwa za Wladysława IV, „Rozprawy Wydziału Historyczno-Filozoficznego PAU", seria II, t. 42 (67), nr 6, Kraków 1930; idem, Granica polsko-moskiewska wedle pokoju polanowskiego (wytyczona w latach 1634-1648), Kraków 1934 (odb. z „Prac Komisji dla Atlasu historycznego Polski”, z. 3). Zob. tcż artykuły W. Lipińskiego w „Przeglądzie Historyczno-Wojskowym”, tam m.in.: Materialy i źródła do wojny smoleńskiej 1632-1634 (1930, t. 2, z. 1, s. 119-141); Stosunki polsko-rosyjskie w przededniu wojny smoleńskiej 1632-1634 i obustronne przygotowania wojskowe (1931, t. 4, z. 2, s. 235-271); Poczq̨tek dzialań rosyjskich w wojnie smoleńskiej (1932, t. 5, z. 1, s. 29-62); Działania wojenne polsko-rosyjskie pod Smoleńskiem od października 1632 do września 1633 r. (1932, t. 5, z. 2, s. 165-206); Organizacja odsieczy i dzialania wrześniowe pod Smoleńskiem w roku 1633 (1933, t. 6, z. 2, s. 173-225); Bój o Zaworonkowe wzgórza i osaczenie Szeina pod Smoleńskiem (16-30 październik 1633 r.) (1934, t. 6, z. 1, s. 39-74); Relacja Krzysztofa Radziwilla z wojny moskiewskiej 1632-1634 (1934, t. 7, z. 1, s. 116-121); Kampania zimowa 1633/34 i kapitulacja Szeina (1934, t. 7, z. 2, s. 217-255). 
go odsłaniają z kolei faktyczny bilans zysków i strat (szczególnie terytorialnych), jakie poniosła Rzeczpospolita w związku z kampanią smoleńską Szeina. Rosjanie wkroczyli wówczas na tereny pogranicza i do znaczących twierdz, takich jak Dorohobuż, Biała, Rosław, Starodub, Trupiesk, Newel, Siebież, Krasne, uzyskanych razem z przylegającymi do nich ziemiami przez Rzeczpospolitą jeszcze za panowania Stefana Batorego czy Zygmunta III Wazy. Ich przynależność do państwa szlacheckiego potwierdzał pokój w Jamie Zapolskim (1582) i rozejm dywiliński z 1619 roku. Na mocy traktatu polanowskiego, jak również w toku prac komisji delimitacyjnej, która działała do roku 1648, Rzeczpospolita odzyskała większość zamków zajętych podczas kampanii Szeina; w tym obleganą bez powodzenia przez Władysława IVw 1634 roku Białą. Utraciła natomiast Trubczewsk i Achtyrkę oraz południowo-wschodnią część ziemi smoleńskiej. Kampania smoleńska Szeina, mimo że nie zakończona zdobyciem twierdzy, zatrzymała terytorialną i dynastyczną ofensywę Rzeczypospolitej na wschód. Władysław IV zrzekł się praw do tronu moskiewskiego.

Miarodajnym źródłem są diariusze pozostawione przez świadków tamtych zdarzeń. Do najważniejszych należą wyzyskane przez Lipińskiego: Diariusz... Jana Moskorzewskiego ${ }^{5}$, obszerny anonimowy diariusz wydany przez Olega Celewicza ${ }^{6}$, a także odnalezione przez Ksawerego Liskego w archiwum w Królewcu relacje agenta elektora brandenburskiego Weinbeera ${ }^{7}$ oraz Relacja wojny moskiewskiej, którq do kr[óta] JM. ks[iqżż] Radziwitf... czynit w Warszawie na sejmie $w$ lipcu $1634^{8}$. Źródłem wartościowym ze względu na przedstawienie szerszego kontekstu politycznego oraz bieżącej oceny wydarzeń jest też łaciński pamiętnik Albrychta Stanisława Radziwiłła ${ }^{9}$, chociaż ten informacje o przebiegu kampanii smoleńskiej głównie powtarza za Moskorzewskim. Dla konfrontacji wizji literackiej z rzeczywistością nieodzowne okazują się sztychy Wilhelma Hondiusa z kolejnych etapów batalii smoleńskiej ${ }^{10}$.

Szczegółową listę źródeł i materiałów zestawia Wacław Lipiński w pierwszym artykule cyklu poświęconego wojnie moskiewskiej ${ }^{11}$. Nowszych informacji o źródłach dostarcza badacz epiki Twardowskiego, Marian Kaczmarek, który wymienia trzy pozostające w rękopisie i nieznane

\footnotetext{
5 Zob. J. Moskorzewski, Diariusz wojny moskiewskiej 1633 roku, opr. A. Rembowski, Warszawa 1895.

${ }^{6}$ Zob. O. Celewicz, Uczast' Kozakiw w smolenskoj wijni, „Zapisky Naukogogo Towaristwa imeni Szcwczenka”, Lwów 1899, t. 28, s. 1-72.

7 Zob. K. Liske, Przyczynki do historii uojny moskiewskiej 1633-34 wraz z planem oblezżnia Smoleniska, "Bibliotcka Ossolińskich", 2, Lwów 1868, s. 1-65.

8 Zob. W. Lipiński, Relacja Krzysztofa Radziwitta..., op. cit., s. 117-121.

9 Zob. A. S. Radziwiłł, Mernoriale rerum gestarum in Polonia 1632-1636, wyd. A. Przyboś, R. Żclewski, t. 1-5, Wrocław 1968-1975; tekst polski w: idem, Pamiętnik o dziejach w Polsce, tł. i opr. A. Przyboś, R. Żclewski, t. 1-3, Warszawa 1980. ${ }_{10}$ Zob. J. Pleitner, Smolenscium urbs ope divina Vadislai IV..., Gedanii 1636; wydane na poleccnic Władysława IV dwukrotnic: w 1636 i 1640 r. (tego 2. wyd. — z objaśnieniami jednego z największych poetów śląskich, Martina Opitza - nie notuje Bibliografia polska K. Estreichera). Rytownik Wilhclm Hondius pracował na podstawic szkiców sytuacyjnych królewskicgo inżynicra Jana Pleitnera.

I Zob. W. Lipiński, Materialy i źródla ..., op. cit., s. 129-131; tam też dzicjc obu wydań sztychów Hondiusa oraz zmian w ich opisach. Na temat kampanii smoleńskicj zob. takżc: E. Kotłubaj, Odsiecz Sinoleńska i pokój polanowski, „Czas” Dodatck miesiçczny, t. 12, 1858, z. 34, s. 91-160; W. Czermak, Wojna Smoleńska z roku 1633-34 w swietle nowych źródet, „Kwartalnik Historyczny”, R. 10, 1896, z. 4, s. 733-755; T. Korzon, Dzieje wojen i wojskowości, t. 2, Warszawa 1912, s. 261-286; J. Łoski, Wilhelm Hondius, nadworny ritownik dwóch królów polskich, „Bibliotcka Warszawska” 1882, t. 1, z. 3, s. 357-368. Z późniejszych prac o charakterze ogólnym: Zarys dziejów wojskouości polskiej do roku 1864, t. 1, Warszawa 1965, s. 457-466; H. Wisner, Wadyslaw IV Waza, Wrocław 1995 oraz szczcgólowe prace na temat panowania Władysława IV: M. Nagielski, Gwardia przyboczna Wadyslawa IV (1632-1648), „Studia i Materiały do Historii Wojskowości”, t. 27, 1984, s. 113-145; W. Kaczorowski, Stanowisko Stolicy Apostolskiej wobec elekcji królewicza Wladyslawa, „Odrodzenic i Reformacja w Polsce”, R. 29, 1984, s. 155-166; idem, Sejm konw'okacyjny i elekcyjny w okresie bezkrólewia 1632 r., Opolc 1986; idem, Koronacja Wladyslawa IV w roku 1633, Opole 1992.
} 
Lipińskiemu anonimowe diariusze wojny moskiewskiej ${ }^{12}$. Ważniejsze XVII-wieczne utwory literackie poświęcone wojnie moskiewskiej omawia ogólnie Juliusz Nowak-Dłużewski ${ }^{13}$; nie są to zazwyczaj teksty o szczególnej wartości literackiej, świadcząjednak — podobnie jak duża liczba diariuszy - o dużym zainteresowaniu współczesnych wojną toczoną na wschodnich rubieżach szlacheckiego państwa.

Wynikało ono ze sposobu rozwiązywania przez króla i jego dowódców trudności, jakich przysparzała ta wojna. Król, by przeciwstawić się Rosjanom, musiał dokonać przede wszystkim reformy armii Rzeczypospolitej, wzmocnić piechotę oraz artylerię i utworzyć oddziały inżynieryjne. Dysponując ponadto znacznie mniejszymi siłami, doprowadził do rozerwania oblężenia miasta i zamknął przeciwnika w obozie, pozbawiając go możliwości kontaktu z zapleczem. Armia Szeina ${ }^{14}$ została pokonana dzięki sprawności dowódczej króla, który w toku kampanii przeprowadził szereg skutecznych działań ofensywnych.

\section{Źródła Twardowskiego}

Nie wskazano dotychczas bezpośredniego źródła, do którego sięgnął Twardowski, przypuszcza się jedynie, że był to diariusz któregoś z uczestników zmagań. Nowak-Dłużewski sądzi, że musiał on pochodzić $z$ kancelarii królewskiej ${ }^{15}$. Jednak realiów przekazanych przez poetę nie da się dopasować do żadnego z zachowanych tekstów. Ponieważ autor na pewno korzystał z przekazów ustnych, wskazanie jednego źródła pisanego wydaje się dziś niemożliwe. Być może poeta, zainteresowany cieszącą się dużą popularnością wojną smoleńską, zbierał do Ekspedycyi relacje mówione i oficjalne komunikaty kancelarii królewskiej ${ }^{16}$, umieszczając je we własnym raptularzu? Mógł też mieć dostęp do diariuszy dygnitarzy czy korespondencji dyplomatycznej za pośrednictwem brata stryjecznego, Zygmunta, który był sekretarzem króla Władysława ${ }^{17}$.

\footnotetext{
${ }^{12}$ Zob. M. Kaczmarck, Barokowe epinicion Samuela Twardowskiego. Z badan nad polska epikq historycznq XITI u., „Littcraria” 1969, z. 1, s. 21, przyp. 32.

${ }^{13}$ Są to: A. Dębołęcki, Triumfi winszowanie, Kraków 1633; Wróżit boju moskieuskiego, Toruń 1633; H. Chełchowski, Wieśé z Moskwvy prawdziu'a, Toruń 1634; J. Schlichting, Pieśn o królu polskim Władyslawie IV, Wielkim Staunym Zawołanym monarsze, Wilno 1635; Nowa pieśn abo triumf moskiewski, [b.m.] 1634; Pieśn dzį̨kczymna, rps Bibliotcki Kórnickiej PAN, sygn. 12831; Biblioteki Ossolineum, sygn. 3585II i in. Zob. J. Nowak-Dłużcwski, Okolicznościowa poezja polityczna w Polsce, t. 5: Dwaj mfodsi Wazourie, Warszawa 1972, s. 16-36.

${ }_{14}$ Wg Albrychta Radziwiłła Michał Borysowicz to postać tragiczna. Nic dość, żc jako wojewoda smolcński utracił miasto w wyniku działań Zygmunta III Wazy i spędził w nicwoli Rzeczypospolitcj dzicwięć lat, to „...pragnął odzyskać utraconą sławę przez odzyskanie Smoleńska. Ale jeszcze większą okrył się hańbă, wydawszy w ręce nieprzyjaciół cały sprzęt wojenny". Zob. A. S. Radziwitł, Pamiętnik o dziejach w Polsce, op. cit., s. 372-373.

${ }_{15}$ Zob. J. Nowak-Dłużcwski, op. cit., s. 20.

${ }^{16}$ Zob. W. Czapliński, W7adyslaw IV i jego czasy, Warszawa 1976, s. 163: „Król, doceniając znaczenic swego powodzenia, kazał spisać uniwersały z doniesieniem o sukcesic, nakazując je starostom "na micjscach zwykłych obwołać i publikować». Równocześnie rozpoczęto druk podobnych uniwersałów w języku niemieckim, by je wysłać za granicę Polski". Tckst jednego z nich podaje W. Lipiński, Bój o Żaworonkowe Wzgórza..., op. cit., s. 40-41.

17 Zob. J. Tokarski, Klopoty literata sprzed lat trzystu, „Kurier Poznański” 1939, nr 242, s. 14-15; idem, Skąd nouve szczególy o Twardowskim?, „Kuricr Poznański” 1936, nr 113, s. 20-21. W pierwszym tekście o kontaktach Twardowskicgo z dworcm królewskim: „Trzymał się Władysława IV, choć jego możny protektor, grabia na Lesznic Bogusław Leszczyński, tumulty przcciw Władysławowi IV czynił i opozycję montowal. Brat stryjeczny, Zygmunt Twardowski (z Twardowskich spod Pleszewa), był sckretarzem Władysława IV, toteż pocta miał liczne kontakty i konszachty
} 
Inaczej w przypadku drugiego utworu, pisanego później, już po opublikowaniu wypowiedzi innych autorów. W ustaleniu źródeł do Wtadysława $I V$ pomaga pośrednio sam Twardowski na początku punktu V. Zastrzega się w nim, że nie jest jedynym autorem podejmującym się opisania dziejów króla Władysława, i zastanawia się, czy potomni uznaja jego wersję wydarzeń, tak przecież dobrze znanych całej społeczności szlacheckiej, za wiarygodną.

$$
\text { ...Jeśli i mnie wiarę }
$$

Da wiek późny, że czego pełno w uściech wszędzie,

Téz i z mego pułpitu dźwięku co przybędzie.

$$
\text { (Wadystaw } I V, 218 \text { ) }
$$

Nasuwa się pytanie: na podstawie czego autor dopełnia dotychczasowe relacje? Zapewne sięgnął po dawniejsze notatki zgromadzone do Ekspedycyi i na pewno wykorzystał gotowy już utwór. To jednak nie wszystko. Opis wojny moskiewskiej stanowił część szerszego zamierzenia: obszernego utworu epickiego o życiu Władysława IV. Twardowski musiał więc zgromadzić znacznie bogatszy material.

Podstawowym źródłem Whadystawa IV było ogólnodostępne w latach czterdziestych XVII wieku lacińskie dzieło panegiryczno-historyczne Everharda Wassenberga, Gestonm Vadislai IV... ${ }^{18}$. Twardowski przejął główny zarys układu materiału książi ${ }^{19}$ przedstawiającej dzieje króla od narodzin do roku 1635 (przebieg wojny smoleńskiej opisał Wassenberg w cz. I, ks. 2, t. II) ${ }^{20}$.

Jak podaje Władysław Czapliński, król zamierzał powierzyć sporządzenie relacji o przebiegu wojen polsko-moskiewskich Wlochowi, Giovanniemu Ciampoliniemu, zbierał w tym celu materiały, do których mógł mieć dostęp zarówno Wassenberg ${ }^{21}$, jak też Twardowski za pośrednictwem stryjecznego brata. Poeta musiał jednak korzystać z ogłoszonej pracy historyka królewskiego, bowiem gdyby oparł się na materiałach z kancelarii władcy, wprowadziłby zapewne własny ich układ. Zależność tę potwier-

\footnotetext{
z Warszawką, miał ścisłe rclacje i materiały z pierwszcj rçki. Umiał je też tak w pocmatach swych wykorzystać, prosto i z impetem, a bez farby pisząc, ze dzicła jego poctyckicj Muzy za najlepsze źródła staja”.

18 Zob. E. Wassenberg, Gestormm glorissimi ac invictissimi Vadislai IV Poloniae et Sueciae regis pars secunda, Gedanii 1643; K. Estrcicher, Bibliografia polska, t. 32, Kraków 1938, s. 441.

19 Dzicło opublikowane trzykrotnie w Gdańsku w latach 1640, 1643 i 1649 dzicli siç na dwa tomy po trzy ksiçgi (te zaś na czçści). Twardowski zachował tylko podział na księgi. M. Kaczmarck (Epicki kształt poematów Sammela Twardowskiego, Wrocław 1972, s. 72, 77) zwraca uwag̨ na zapożyczenic formy opisu hołdu ksiçcia moskicwskicgo przed wysłannikiem chana tatarskicgo i na relację w punkcic I Whadysława $I V$, dotyczącą okresu dymitriady w Rosji. ${ }^{20} \mathrm{~W}$ ks. 2, t. II autor opisał w kolcjnych czçściach: 1. kampaniç smolcńską, następujące zaraz potcm 2. zmagania z Turcją i 3. rokowania pokojowe ze Szwecją. Najwiçcej micjsca (89 ss.) poświęcił wojnie smoleńskicj, pozostałe dwic czçści obejmują łącznic 62 strony. Twardowski połączył w punkcic V te trzy czçści, zachowując podobną strukturę opisu. Podział materiału zastosowany przez oficjalncgo kronikarza królcwskicgo ułatwia wyodrębnienic, zlewającego sic̨ u Twardowskicgo w jedno, przebiegu trzech wojen: smoleńskicj, tureckicj i spodzicwancj szwedzkiej. Być możc Twardowski w ślad za Wassenbergiem umieściłby w VI punkcic nicdokończoncj opowicści o Władysławie IV: opis podróży króla do Wilna, odznaczenic Sarbiewskiego, ślub i koronację Cecylii Renaty oraz narodziny królewicza Zygmunta Kazimierza 1 kwictnia 1640 roku.

${ }^{21}$ Zob. W. Czapliński, op. cit., s. 333-334. Ze wstępu historyka królewskiego można dowiedzicć sic̨, że korzystał z wiadomości od Kaspra i Pawła Działyńskich, Jerzego Ossolińskicgo i Gerharda Dönhoffa, czyli od najblizszych współpracowników władcy. Jednak mimo to pancgiryczne dzicło nie cicszyło się zaufanicm późnicjszych badaczy dziejów. Pod hasłem Wassenberg, K. Estreicher (op. cit.) przytacza krytykę Ksawerego Liskego (ibidem, s. 1-65), który zestawił przckaz Wassenberga z relacjami Weinbecra, wysłancgo pod Smolcńsk z ramicnia clcktora brandenburskicgo.
} 
dza choćby przywołanie pod koniec opisu kampanii moskiewskiej tego samego napisu na jednym z łuków triumfalnych wystawionych w Warszawie na powitanie króla. W Gestonum Vladislai IV jest to epigram następującej treści:

Teuto, Anglus, Gallus, Batavisque, Gothusque, Scotusque ad Moscum toto venerat Oceano.

Arma, viros, artes, longinquus miserat orbis, iamque ferox belli viribus hostis erat.

Addidit ipse dolos, et rupto foedere pacis, perfida securis intulit arma locis.

Rex Vladislaus venit cunctosque coegit, hinc invita, illinc supplici abire fuga.

Teuto, Anglus, Gallus, Batavusque, Gothusque, Scotusque scis quid erat? Hosti pompa fuere, nugae ${ }^{22}$.

Twardowski przełożył tekst, zmieniając jedynie kolejność wyliczanych nacji:

Niemiec, Francuz, Szwed, Anglik, Belga przeciw panu

Ze wszytkiego do Moskwy przyśli oceanu.

Armat, kunsztów, dowcipów dodał świat daleki,

Czym tuszeł nieprzyjaciel zgubić nas na wieki.

Dodał samże zdrad swoich, przymierze złamawszy,

I wiele tym bezpiecznych miejsc zruinowawszy.

Król Władysław tych wszytkich skoro przeszedł razem,

I tam, i sam rozegnał ostrym swym żelazem.

Niemiec, Francuz, Szkot, Anglik, Szwed i z Belgą niskiem

Wiesz, czym beli w Warszawie? - Pompą i igrzyskiem.

(Wadystaw IV, 263)

Jednak o ile koncepcję struktury dzieła Twardowski przejął bez większych zastrzeżeń od Wassenberga, o tyle zarówno fakty przekazywane przez historyka królewskiego, jak też ich oceny modelował w myśl własnych poglądów. Stosował też samodzielnie wypracowana, oryginalną technikę epickiego przedstawiania zdarzeń. Jeśli posiadał dokładniejsze informacje, wprowadzał je do opowieści, dbając o wierność prawdzie historycznej.

Dla ustalenia źródeł poety istotna wydaje się również odpowiedź na pytanie: gdzie znajdował się przyszły autor Wtadysława IV podczas kampanii? Trudno powiedzieć czy był pod Smoleńskiem. Pewne poszlaki pozwalają jednak określić przybliżone miejsce jego pobytu. Stanisław Turowski twierdzi, że Twardowski nie walczył pod Smoleńskiem ${ }^{23}$, był natomiast u boku swojego ówczes-

${ }^{22}$ Zob. E. Wassenberg, op. cit., s. 138.

${ }^{23}$ Zob. S. Turowski, Samuel ze Skrzypny Twardowski i jego poezja na tle wspótczesnym, Lwów 1909, s. 18, przypuszcza, że poeta walczył w oddziałach Wiśniowieckiego. Jan Okoń (zob. Wstęp, w: S. Twardowski, Dafnis drzewem bobkouym, opr. J. Okoń, Wrocław 1976 (BN I 227), s. IV-XII) nic ustosunkowuje sic̨ do udziału Twardowskicgo w konfliktach zbrojnych. 
nego mecenasa, Janusza Wiśniowieckiego, w oddziałach Stanisława Koniecpolskiego, wysłanych na południowy-wschód przeciw Mehmedowi Abazemu baszy ${ }^{24}$.

Poeta istotnie związany był z Wiśniowieckim (od roku 1633 do niespodziewanej śmierci magnata w listopadzie 1636 roku) i pod jego opieką wydał w 1633 roku Przeważnq legacyję... oraz otrzymał w dzierżawę Zarubińce ${ }^{25}$. Zastanawia jednak przyczyna, dla której opublikował Ekspedycyje w Warszawie, a nie na przykład w Krakowie czy Lublinie. Pomijając udział poety w walkach z 1633 roku, trzeba rozważý, czy faktycznie, jak chce Turowski, uczestniczył on w spotkaniu z armią cesarza tureckiego Amurata IV, latem 1634 roku. Przeciw udziałowi twórcy w zmaganiach na południowym wschodzie przemawia fakt, że nie poświęcił tamtym zdarzeniom żadnego osobnego utworu. Uczcił jedynie hetmana w zbiorowym panegiryku Sieradz się świeci pod wjazd jaśnie Wielm.[ożnego] J.[ego] M.[ósi] P.[ana] Stanistawa Koniecpolskiego ${ }^{26}$.

Ale warto sięgnąć do poematu Ksiażę WiśniowieckiJanusz... . Czy autor miał okazję zobaczyć wojsko Koniecpolskiego i Wiśniowieckiego oraz armię smoleńską pod Kamieńcem Podolskim, gdy zgromadziły się, czekając na przybycie wojsk tureckich pod wodzą cesarza? Prawdopodobnie tak. Przekonanie to potwierdza dobra orientacja poety w wyglądzie obu armii:

Z tym sercem i ochota przy wielkim hetmanie

Wszytek wybór i obóz pod Kamieńcem stanie,

Gdzie przybył i książę mój z wojskiem ludzi swoich;

Tu sprawuj już Erato i w piersiach tchni moich! -

Co tedy był za widok? Co nań za oczema

Wojsko wszytko patrzyło? Gdy trzydziestą trzema

Chorąwiami okryty wjeżdżał do obozu,

A jako z słonecznego wypierzchają wozu

Promienie i polory, ze zbroj się zrażały,

Konie ogień z ochoty nozdrzema pryskały,

Rzędy po nich i forgi ciężały od złota,

A we wszytkich jedna chuć, serce i ochota.

$Z$ reimentem złoconym wódz sam przed wszytkiemi,

Zdał z konia się wyrastać i nie tykać ziemi (...).

A wtym też, ukróciwszy północne Tryjony,

Wybór z Moskwy powracał on niezwyciężony.

Jaką twarzą ogromni nieśli się i strojem,

Niegdy Argiraspide z Aleksandrem swojem.

\footnotetext{
24 Ten dowodzący Tatarami możnowładca bez zgody sułtana rozpoczął nieskuteczne działania przeciw Rzcczypospolitej, za co został stracony w 1634 roku na polecenie Amurata IV. Spotkał go więc podobny los, jak naczclnego dowódcę wojsk moskicwskich Szeina.

${ }_{25}$ Zob. J. Okoń, Wstẹp, w: S. Twardowski, Dafnis..., s. X-XI; R. Ryba, „Ksiqż̨̨ Wiśniowiecki Janusz” Samuela Twardowskiego na tle bohaterskiej epiki biograficznej siedemnastego wieku, Katowicc 2000, s. 24-25.

${ }^{26}$ Zob. S. Twardowski, Miscellanea selecta... W różnych panegirycznych okazjach do druku sparsim podane, teraz jako godne pamięci $w$ jedno opus zebrane, Kalisz 1682, s. 80-93.
} 
Było i tu co widzieć, one gdy się zeszły

Wojska tryumfujące $(\ldots)^{27}$.

Twardowski mógł więc obserwować oddziały wkraczające do obozu pod Kamieńcem. Formę „my” poeta stosuje, wypowiadając się w imieniu całej społeczności szlacheckiej Rzeczypospolitej, nie można więc na podstawie osoby gramatycznej wiązać go z którymś oddziałem. Jego uwagę zwraca nowo zorganizowane, błyszczące złotem wojsko Janusza Wiśniowieckiego. Zgodnie z prawdą przedstawił też wygląd bohaterów smoleńskich, o których nie miał przedtem wiele do powiedzenia. Wymowne milczenie Twardowskiego zdaje się pozostawać w zgodzie $z$ wypowiedzią Pawła Piaseckiego, według którego wojska przybywające spod Smoleńska na przedpola Kamieńca nie wyglądały zbyt dobrze:

....a ten [żołnierz], co opieszale nadciągał z Moskwy, stawał niepełnymi w ludziach, w koniach i orężu znacznie uszkodzonymi rotami ${ }^{28}$.

Nakreślony przez Twardowskiego obraz przybywających z Księstwa Moskiewskiego oddziałów dotyczy raczej nastroju panującego wśród wojskowych.

Należy więc przyjąć, że Twardowski był pod Kamieńcem w oddziałach Wiśniowieckiego i Koniecpolskiego, gdzie uzupełnił swoje informacje wiadomościami od uczestników walk. Wkrótce potem, to jest późnym latem albo jesienią, znalazł się w Warszawie, gdzie opublikował pod koniec roku Ekspedycyje. W tym samym czasie, zapewne w drodze powrotnej ze stolicy na Podole, wydał w Lublinie osobny utwór poświęcony zmarłemu 20 listopada królewiczowi Aleksandrowi Karolowi ${ }^{29}$.

\section{Wizja literacka a prawda historyczna}

Zestawienie poetyckiej i historycznej wizji poety z pracami historyków prowadzi do wniosku, że relacje Twardowskiego odpowiadają prawdzie historycznej. Autor, adresując wypowiedź do współczesnych czytelników, naraziłby się na odrzucenie z ich strony, na pogardę i lekceważenie, a może i utratę honoru, gdyby nie przedstawiał wypadków w zgodzie z tym, co opowiadali uczestnicy walk. Tę wierność przebiegu zdarzeń miały potwierdzać również przywoływane z kronikarską dokładnością (niczym w diariuszu Moskorzewskiego ${ }^{30}$ ) oficjalne dokumenty. Ma to miejsce w końcowych partiach tekstów, gdy autor przedstawia najpierw zaproponowane przez Rzeczpospolitą warunki zakończenia walk, oraz później, gdy przywołuje postanowienia traktatu polanowskiego. W Ekspedycyi daje jakby wyciag z traktatu pokojowego, we Wtadystawie IV znajduje miejsce na wymienienie wszystkich zamków i uwzględnia inne liczne szczegóły:

\footnotetext{
${ }^{27}$ Idem, Książ̨ Wiśniowiecki Janusz. Koniuszy koronny i krzemieniecki starosta, Lcszno 1646, s. 45-46 (dalcj: KWJ $z$ paginacją w nawiasach).

${ }_{28}$ Zob. P. Piasecki, Kronika, wst. J. Bartoszewicz, tł. A. Chrząszczewski, Kraków 1870, s. 402.

${ }^{29}$ Znany z osobnego wydania u Pawła Konrada. Na egzemplarzu wg K. Estreichera (op. cit., t. 31, s. 437) brak daty druku, bibliograf dopisał rok 1634.

30 Pełen tckst Kondycyj pokoju wiecznego z Moskwq zawartych dnia 13 czenvca roku 1634 zob. J. Moskorzcwski, op. cit., s. $132-133$.
} 
Punkt beł pierwszy: Żeby król do carstwa wielkiego

Ustąpił prezencyji i prawa swojego,

Wlawszy na Fedrowicza odtąd je Michała,

Tyle w nim ku poddanym miełość sprawowała,

Że gwoli pospolitej sprawie i potrzebie

Wprzód, niż nieprzyjaciela, sam zwyciężeł siebie.

Jako także wielki car z drugiej za to strony,

Które księstwa do Litwy niegdy i Korony

Należały, przez wojnę odpadłe przed laty,

Siewior, Smoleńsk, Czerniechów społem z ich powiaty

I grodami wszytkimi, i armatą całą,

Nowogródkiem, Rosławiem, Drohobużem, Białą,

Sierpiejskiem, Starodubem, Newlem, Moroskłonczą,

Siebieżem, Krasnobrodem i które się kończą

Aż po szlaki morawskie miasta i posady

Tak, żeby dla na potym jakiej o to zwady

Tych prowincyj tytułu i żadnej już więcéj

Odtąd prerogatywy nie nosił książęcej (...).

(Wladystaw IV, 261-262)

Cokolwiek między państwy było stąd niechęci,

Wszytko wzajem utopią w wiecznej niepamięci.

Król do carstwa wielkiego

Ustapi prawa swego.

Tyle w nim krew i miłość swoich sprawowała,

Że w pół biegu szalone koła zatrzymała:

Spólnej gwoli potrzebie

Zwyciężył wprzód sam siebie.

A car wiecznie siewierskich zarzec się ma włości,

Oddać miasta i grody bez żadnej trudności,

Nie dochodzić Estonów,

Zapomnieć i Liwonów.

Więźnie wszytkie wypuścić, ani przeciw sobie

$\mathrm{Z}$ niechętnymi przestawać strony mają obie,

Między ziemią oboja

Granice uspokoją.

Kupcy handle z obu stron będą mieć bezpieczne,

Miasta oprócz oboje wyjąwszy stołeczne.

(Ekspedycyja, XV, 49-66)

Poszukując w utworach relacji o wydarzeniach, poetyckiej Ekspedycyi można nie stawiać zbyt wysokich wymagań historycznych, lecz Wtadystaw IV to epos pisany z myślą o potomnych, a celem autora było utrwalenie przebiegu walk i bohaterstwa uczestników. Oczekując dobrego odbioru 
i poczytności, poeta dbał o zachowanie prawdy historycznej. Tekstu Twardowskiego nie można jednak traktować jako rymowanej kroniki. Autor postrzega wydarzenia z perspektywy szlachcica-rycerza i ten punkt widzenia przekazuje odbiorcy, wpisując w utwór, sformułowaną w retorycznej konwencji, wartościującą interpretację współczesnej sobie rzeczywistości. Jedynym sposobem manipulacji wypadkami mogło być najwyżej przemilczanie wstydliwych faktów.

\section{Konstrukcja świata przedstawionego i bohatera}

\section{Struktura relacji wojennej}

Złożoną z szesnastu części (nazywanych „wierszami”) Ekspedycyję autor poprzedza dedykacją Władysławowi IV Wazie, zaznaczając, że będzie opisywał jego sukcesy „piórem ojczystym”, że jego sztuka wyrasta z rodzimej, nie zaś antycznej tradycji, a jego muzy „Dniepr piją gruby”.

Każdy „wiersz” poświęcony jest innemu wydarzeniu kampanii smoleńskiej, przedstawionemu w zgodzie $z$ historią. Autor skondensował jednak znane współczesnym wydarzenia i nadał im poetycką oprawę, by przede wszystkim oddać hołd zwycięskiemu królowi (trudno więc dziś bez znajomości dokładnego przebiegu kampanii smoleńskiej zrozumieć wszystkie odwołania poety, zwłaszcza w odniesieniu do opisów działań wojennych). Przedstawiając przebieg zdarzeń, twórca nie stara się jednak koloryzować czy przeinaczać faktów. Nie przemilcza więc porażek armii królewskiej, wspomina o nieprzygotowaniu Rzeczypospolitej do wojny moskiewskiej, o grożącej państwu katastrofie. Uczciwie pisze też o zakończonym niepowodzeniem oblężeniu Białej, jak również o trudnościach, jakie napotykali walczący podczas boju o pozycje Damma i Matyzona.

Tekst jest inkrustowany obrazami mitologicznymi, do których odsyłają krótkie sygnały w formie porównań. Dla odbiorcy znającego wydarzenia z innych źródeł nie stanowią one przeszkody, natomiast czytelnik niezorientowany gubi się w gąszczu skrótów myślowych i aluzji historycznych. Czasami reminiscencje mitologiczne pełnią funkcję metafor mających przybliżyć zdarzenia, na przykład w krótkich uwagach na temat wschodów i zachodów słońca. Autor nie rozwija opisu tych zjawisk, szczególnie gdy relacjonuje walkę. Musi z nich zrezygnować, chcąc zachować dynamikę wypowiedzi. Dąży do kondensacji opisu, ponieważ pragnie pozostawić miejsce na uczczenie bohaterów. Relacja jest zatem bardzo sucha, a tekst zwarty, bez komentarzy do zdarzeń i bez bogatszych, niezwiązanych z mitologią porównań.

W utworze można wyodrębnić sekwencje statyczne (pieśni ku czci zwycięzcy, przedstawiające działania pozamilitarne, lub peany na jego cześć) i dynamiczne: opisy gwałtownych, prowadzonych często ze zmiennym szczęściem walk. Całość ma charakter często liryzowanej, jednak zdecydowanie epickiej relacji z wojny. W sensie genologicznym Ekspedycyja jest bowiem epinikionem, czyli pieśnią na cześć zwycięzcy ${ }^{31}$.

Pisząc punkt V Wladysława $I V$, poeta zmienił wstępne założenia i sposób prezentacji faktów. Dla lepszej orientacji czytelnika wprowadza na marginesie tekstu uwagi lokalizujące zdarzenia

\footnotetext{
${ }^{31}$ Zob. M. Kaczmarek, op. cit., s. 36-37; M. Kuran, Stefan Batory i Wtadysław IV - poetyckie wizje wypraw moskiewskich (epinicion, panegiryk, kronika), w: Od średniowiecza ku wspótczesności. Prace ofiarowane Jerzemu Stamawskiemu w pięćdziesięciolecie doktoratu, rcd. J. Okoń, wspólpr. M. Kuran, Łódź 2000, s. 306-323.
} 
i osoby: daty dzienne czy nazwiska dowódców; z owych marginaliów można by ułożyć bardzo czytelne streszczenie tekstu. W samym opisie przebiegu walk autor znajduje miejsce na swobodne, rozbudowane porównania i rozległe metafory odwołujące się zarówno do mitologii, jak i zjawisk natury. Wprowadza też dygresje. Do największych należy relacja o zwycięskiej akcji przeciw Mehmedowi Abazemu baszy. Wplata ją w opowieść smoleńską w chwili, gdy przybywają do króla posłowie tatarscy z prośbą o pokój i propozycją wspólnej akcji przeciw Moskwie ${ }^{32}$. Relację tę otwiera przedstawienie magnatów, którzy podjęli się, nie czekając na pomoc ze strony króla, obrony południowo-wschodnich granic. Zwraca tu szczególnie uwagę opis postawy mecenasa Twardowskiego, Janusza Wiśniowieckiego, który wsparł prywatnymi wojskami hetmana Koniecpolskiego; był:

Miedzy pierwszy którymi z wojskiem się swym stawi

Wiśniowiecki koniuszy i sobą zabawi

Oczy wszytkich życzliwe, niosąc pełną postać

Marsa posępionego. - O, gdzieżby go dostać

Nadobnej Galatei? gdzie Napejom wodnym,

Żeby go utrzymały wzrokiem swym lagodnym

W cerze tej popędliwej? - Wielkim on Atlasem

Beł tej wojny i murem, kiedy przed tym czasem

Żadnej o pogańskiego wojska wiadomości

Pewnej liczbie nie beło, on, z zwykłej czułości

Miał ją pierwszy i zatym, bok zabiegszy prawy,

Czekał prętko szczęśliwej w polu z nim rozprawy

(Wtadystaw IV, 248-249) ${ }^{33}$.

Poeta wprowadza również inne dygresje. Wszystkie one służą jednak wątkowi głównemu, wyjaśniają motywy działań postaci, rozszerzają relację wypadków o niezbędny kontekst; na przykład opis przybycia posła tatarskiego pod Smoleńsk poprzedza retrospektywę stosunków rosyjsko-tureckich, z odesłaniem po szczegóły do Przeważnej legacyji... Taką dygresję stanowi też skrótowy opis wyboru króla, zamieszczony po relacji na temat sytuacji twierdzy smoleńskiej. Uzupełnienie to jest niezbędne, ponieważ autor wprowadza w nim do akcji głównego bohatera.

\section{Bohater}

Głównym bohaterem obu tekstów i zarazem adresatem pierwszego z nich pozostaje król, Władysław IV. Zajmuje on eksponowane miejsce nie tylko z tytułu godności monarszej, ale również ze względu na faktyczne zasługi. Od momentu przybycia do obozu pod Orszą był głównodowodzącym w kampanii smoleńskiej. Jego rola była podwójnie trudna. Musiał samo-

\footnotetext{
32 O strukturze „Wadysłwa IV” zob. S. Stalmann, Die historischen epen von Samuel ze Skrzypny Twardowski, Bonn 1971, s. $135-141$.

${ }^{33}$ Autor po raz picrwszy i nicco szerzcj opisał ten cpizod w epicedium, poświęconym postaci dzicdzica rodu Zbaraskich, Ksiq̨żę Wiśniowiecki Janusz (op. cit., s. 42-46), które zadedykował synom bohatera.
} 
dzielnie przygotować armię, począwszy od werbunku wojska (ponieważ zobowiązany do tego hetman wielki litewski Lew Sapieha w ogóle nie wierzył w wojnę z Moskwą, a gdy armia rosyjska przekroczyła granicę, tłumacząc się wiekiem i złym zdrowiem nie podejmował stosownych działań ${ }^{34}$ ), prowadzić skomplikowaną kampanię przy wsparciu skłóconego sztabu, w którym Krzysztof Radziwiłł rywalizował $\mathrm{z}$ hetmanem wielkim koronnym Marcinem Kazanowskim, wreszcie pokonać wroga, dysponując znacznie mniejszymi siłami. Przy okazji przygotowań do wojny smoleńskiej król dokonał gruntownej reformy wojska, położył nacisk na wzmocnienie piechoty i artylerii, utworzył wojska inżynieryjne ${ }^{35}$. Nieliczna wprawdzie armia Rzeczypospolitej przybyła pod Smoleńsk świetnie przygotowana. Zasługą króla było także opracowanie strategii działań i podjęcie szeregu trafnych decyzji, zwłaszcza w ogniu walki, na przykład w chwili ataku Rosjan na oddziały zajmujące Skowronkowe Wzgórza; po tej decydującej bitwie dowódca moskiewski Szein nie potrafił już zmobilizować oddziałów do przeciwuderzenia i wydostać się z okrążenia, a po kilku miesiącach beznadziejnego oczekiwania na pomoc z zewnątrz skapitulowat ${ }^{36}$.

Władca zajmuje więc w utworach eksponowane miejsce, jednak autor poświęca wiele uwagi również głównym wykonawcom jego woli, którzy zadecydowali o jakości realizowanych zadań: dowódcom poszczególnych formacji oraz szeregowym uczestnikom walk. Ukazuje ich zasadniczo w dwóch sytuacjach: przedstawia bohaterskie czyny oraz opisuje chwalebną śmierć.

W Ekspedycyi Twardowski prezentuje bohaterów, uwzględniając ich hierarchię. W pierwszych wierszach pisze wyłącznie o królu, potem wymienia Krzysztofa Radziwiłła oraz kanclerza Jakuba Zadzika. W wierszu czwartym wprowadza szlachtę, wylicza nazwiska dowódców poszczególnych oddziałów lub czyni ich bohaterami epizodów. Zachowując tę strukturę opisuje śmierć walczących. Szeregowa szlachta działa jako bezimienna zbiorowość, reprezentują ich (oraz oddziały jako całości) dowódcy formacji.

Podobnie dzieje się we Wladystawie IV, autor jednak może poświęcić więcej uwagi rycerzom, dlatego wyliczając dowódców, dokonuje prezentacji gromadzących się wojsk i charakteryzuje pochodzenie walczących:

Toż Rożen, Krejć i Butler, gwardyji królewskiej

Pułkownicy nagonią, aż i Arciszewski

Z szlachtą swoją, około Narwie gdzieś i Bzury,

Miedzy starożytnymi zbieraną Mazury. (...)

...Przybywa ze swymi

Wajer także Pruszaki, odkąd szczęśliwymi

Miedzy Drwęca ziemiami krzywo się poczyna

I sama w pół Sambijej Wisła się rozcina

Krajem żyznej Żuławy (...).

(Wtadystaw IV, 226)

${ }^{34}$ Zob. W. Lipiński, Stosunki polsko-rosyjskie..., op. cit., s. 248.

35 Zob. idem, Organizacja odsieczy i działania wrześniowe..., op. cit., s. 196.

36 Zob. idem, Kampania zimowa..., op. cit., s. 217. 
W opisach rozmieszczenia wojsk Twardowski identyfikuje oddział z dowódcą:

Obóz wielki, a w koło miedzy się rozeprze

Blokhauzami dużymi, gdzie Rożen z Wolszamem,

Krejc, Ossiński i Gadun. (...)

Góry owe obiedwie, na pięćdziesiąt kroków

Ledwie z sobą odległe: Plater na Skowrończy,

A Butler na Pokrowie (...).

(Wtadystaw IV, 245)

Tak samo przedstawia oddziały w akcji, akcentując męstwo, odwagę i siłę walczących:

A w tej fali z jezdą swą okrywa się Miński,

Firlej mężny przywodzi, czyni Madaliński

Krusząc drzewa ogromne, a Wajer żarzliwy

I Kawaller, i Butler ogień strzela żywy.

(Wtadystaw IV, 243)

Respektując podobne zasady, wylicza dowódców strony przeciwnej, a mówiąc ogólnie o wrogach, używa określeń typu "Moskwa” albo nazwiska naczelnego dowódcy Szeina. Dane autora o przeciwniku siłą rzeczy są mniej dokładne. Często odnosi się wrażenie, jakby wymieniał je, patrząc na sztabową mapę $z$ opisem ich rozmieszczenia (lub na sztychy Hondiusa). Pełen skład moskiewskiego korpusu dowódczego przedstawia Twardowski w opisie kapitulacji, eksponując negatywne cechy charakteru wodzów:

Przystąpi z drugiemi

Po Białosielskim dumny Artemi,

Suchotyn i pełen troski

On tak hardy Prożoroski. (...)

Rzucił Fuks z Waldonem

Choragwie swoje i z Matyzonem

Tobijasz, społem $z$ strzelcami

Leponow i Szarlijami.

Lessel i Dam z Kithem

Przed Szandersonem poszli zabitem.

Nad jego Anglicy truną

I swoją smutni fortuną

(Ekspedycyja, XIV, 53-56, 65-72).

Mimo ogólnej tendencji do postrzegania swoich pozytywnie, a wroga w złym świetle i z pogardą, potrafi Twardowski docenić siłę militarną armii Szeina. Jednak jego działania mają na celu wyłącznie podkreślenie rozmiaru trudności, jakie mieli do przezwyciężenia rycerze Rzeczypospolitej. 
Gdzie Dam z Niemcy swoimi blokhauz miał kopany

Wynieślejszy nad inne; każe Wajerowi

I, z przybrańszą piechotą, Abramowiczowi

Oń się ważyć, a $z$ boku rozdrażnić Prożora

Zaporożcom (...).

(Wtadystaw IV, 236-237)

Ale choć i dużych ramiony cyklopów,

Nie ruszą okopów.

Sroższe lada rowy i ślepe fortyle,

Aniz moc odkryta męstwu ich i sile,

Przecię w ogień żywy, co serca, co chęci,

Idą bez pamięci.

Aż gdy ciały swymi doły wyrównają,

Że głuche pod ziemią lochy zaszczekają (...)

Juz i Dam we trwodze. (...)

(Ekspedycyja, VII, 27-35)

W ten sposób pokazuje autor przewagę moralną rycerzy Rzeczypospolitej, którzy są na tyle odważni, by stanąć oko w oko $\mathrm{z}$ wrogiem. Jest to szaleńcza walka za wszelką cenę, bez liczenia się $z$ ofiarami. Męstwo równa się tu niemal głupocie, oznacza jednak bezgraniczne oddanie sprawie, które przynosi pożądany efekt. Niezwyciężony dotąd Dam ustępuje.

Nazwiska uczestników walk z obu stron (cudzoziemskie — spolszczone bądź zapisane fonetycznie: „Wolszam” — Wolson, „Matyzon” — Mattison, „Rożen” — Rosen itp.) powtarzają się niekiedy w tekście, w zasadzie jednak nie więcej niż dwa do pięciu razy. Na przykład oficer gwardii królewskiej Butler występuje w cytowanym już opisie prezentacji wojsk Rzeczypospolitej, następnie kilkakrotnie w zmaganiach o Pokrowską Górę, na której pozostał, i kolejny raz w walce o utrzymanie Wzgórz Skowronkowych - w sumie w Ekspedycyi pięć razy. We Wtadysławie IV sześć razy wymienia autor nazwisko Butlera i trzy razy mówi o jego pułku: „Butlerowi ludzie”.

Interesujące okazuje się zestawienie listy nazwisk wymienianych w obu utworach. Autor we Wadystawie IV nie umieszcza 11 nazwisk ze strony Rzeczypospolitej z Ekspedycyi, wprowadza natomiast 37 nowych postaci. Z Ekspedycyi do Wtadystawa IV nie przechodzą dwa nazwiska ze strony moskiewskiej, a nowych przybywa 6. Nazwisk osób obcego pochodzenia niebiorących udziału w walkach (głównie postaci z historii współczesnej Twardowskiemu lub starożytnej) przybywa we Wladystawie $I V$ prawie 20. Powyższe zestawienie pokazuje, że między napisaniem obu tekstów epik zdobył dokładniejsze informacje jedynie na temat strony polskiej, chcąc obszerniej utrwalić zasługi jak największej liczby walczących.

Ważna dla moralnej wymowy obu utworów jest postać Jakuba Wojewódzkiego, obrońcy Smoleńska. To jedyny uczestnik działań wojennych, któremu Twardowski udziela głosu. Autor pozwala mu w czasie obrony miasta wygłosić mowę zachęcającą do dalszego oporu (jedynie we Wtadystawie IV) oraz drugą, po przedarciu się z miasta podczas akcji zaopatrywania twierdzy, skierowaną do króla. Wojewódzki „panu przypada pod nogi” w obu utworach, a mowy zachowują podobną strukturę, chociaż w Ekspedycyi rycerz występuje w imieniu wszystkich obrońców, a we 
Władystawie IV kieruje do króla przemowę bardziej osobistą, podkreślając swoje zaangażowanie w obronę, wysitek i oddanie sprawie:

Życzliwe Nieba, które nam żyć dały

Przez tyle śmierci, że cię tu widziemy!

Już by niech więcej jędze nie drzymały,

Że w oczu twoich wesoło pomrzemy.

Że i z tą wiarą, której przez rok cały

Dotrzymaliśmy, do grobu wnidziemy

Przyjmiej odwagi, przyjmiej trudy krwawe,

A oko za to ukaż nam laskawe.

(Ekspedycyja, VI, 41-48)

...dobrał się do pana i wziął go za nogi:

Dobre Nieba, aż dotąd które mi żyć dały

(Słowa z płaczem mieszając), już by niech skracały

Strapionego żywota i godzin swych teraz,

Kiedy Cię tu dziś widzę. Jakożem ja nieraz

W tamte strony poglądał Twojej tej pomocy

I ratunku czekając. Co niespanych nocy,

Zwyciężonej natury, trudów i niewczasów,

Krzywd niebieskich i nędze do tych zniosłem czasów! -

Wszytko mię to minęło! Zamek masz i mury

Jeszcze wolne, lubo w nich znaczne widzisz dziury,

Ale choćby do gruntu wywrócone i te,

Wiara moja i serce nigdy niepożyte

Przeciw Tobie. Czego mi, wierzę, sam poświadczysz,

A przynamniej mię za to potym nie zabaczysz.

(Wtadystaw IV, 232-233)

Wojewódzki zginął zresztą niedługo po rozerwaniu oblężenia Smoleńska:

W sukcesy tę szczęśliwie żałobliwa zguba

Świeżo Wojewódzkiego zasmuci Jakuba,

Kiedy w jednej wycieczce od swych uniesiony,

Zza szańcu beł szkodliwie w ramię postrzelony

I dotąd się pasował z śmiercią nieużytą.

(WTadystaw IV, 239)

Opisany wyżej epizod i refleksje wypowiadane przez umierającego Wojewódzkiego zawarł Twardowski w osobno poświęconym mu utworze Jakub Wojewódzki pod Smoleńskiem zabit 10 Januar.[ii] ${ }^{37}$.

37 Wyd. w: S. Twardowski, Miscellanea selecta.., op. cit., s. 162-164. 
Wydawca nie podał roku śmierci; warto przy okazji sprecyzować, że Wojewódzki poległ, o czym można się przekonać z marginaliów we Wladystawie $I V$ i relacji Moskorzewskiego ${ }^{38}, 10$ października 1633 roku, a nie 10 stycznia roku następnego ${ }^{39}$. Pomyłka pochodzi, jak się wydaje, od nie do końca zorientowanych kaliskich wydawców wierszy poety. W utworze tym podmiot liryczny, podobnie jak we Wtadystawie $I V$, wypowiada się w pierwszej osobie liczby pojedynczej. Jest to pieśń spoczywającego na łożu, śmiertelnie rannego bohatera, który zapewnia króla, że mu wiernie służył i wytrwał na posterunku do końca. Bohater poświęca swój trud i życie monarsze:

Trudno! wrodzona nie zniosła ochota,

Żebym się tu miał niemężnie szanować,

Nie zniosła wiara i doznana cnota,

Żebym jej nie miał krwią zapieczętować

Widząc ono Pan rumuje sam wrota,

Ostrogi burząc każe następować.

W nim utopiwszy ostatnie swe oczy,

O, jako trzykroć umarłem ochoczy.

Zamkum obronił i różnej fortuny

Wytrzymał szturmy. Raz słowy gładkiemi

Uwodził tyran, razem grzmiał pioruny,

Że dźwięk w ostatniej odzywał się ziemi.

Nie tykaj jędzo, nie tykaj się truny,

Nic tu z potwarzą, nic z Satyry twemi.

Stłuczone mury, belloardy zbite,

Wiara nietkniona, serce nieużyte.

Ale cóżkolwiek odniosłem i użył, Wszystko, o Panie, oddawam to Tobie.

Ty, sam mi przyznaj, że dobrzem ci służył,

Żem przy twem umarł zdrowiu i ozdobie $(\ldots)^{40}$.

Obserwując ewolucję motywu we wszystkich trzech tekstach, trzeba stwierdzić, że z upływem czasu relacja Twardowskiego o dokonaniach podwojewodzica nabiera coraz bardziej osobistego wyrazu. Od „my” w Ekspedycyi i pewnej rezerwy przechodzi do ,ja” w Jakubie Wojenódzkim...: bohater mówi o swoich dokonaniach, jednak jeszcze dość ogólnikowo. We Wladystawie IV autor otwiera jakby duszę bohatera, odsłania przed czytelnikiem świat jego wewnętrznych przeżyć, walkę nie tylko prowadzoną orężem, ale i nocne zmagania się z sobą. Wojewódzki mówi królowi,

\footnotetext{
${ }^{38}$ Dostarczenic posiłków miastu miało miejsce 7 września 1633 roku (s. 231). Wojewódzki ginic podczas wypadu, do którego doszło po rozerwaniu oblężenia. Miało to micjsce między 4 a 16 paździcrnika (pierwsza data we Władyslavvie IV..., s. 238; opis śmicrci Wojewódzkicgo: s. 239; kolejna data: s. 241).

${ }^{39}$ Pomyłka mogła wyniknąć z faktu, że pod Smolcńskicm zginął równicż Stanisław Wojcwódzki, ojcicc Jakuba, wojewodzic, faktycznie odpowiedzialny za obronę twierdzy. Zob. K. Liskc, op. cit., s. 21; P. Piasecki, op. cit., s. 391.

40 S. Twardowski, Jakub Wojewódzki pod Smoleńskiem zabit..., op. cit., w. 17-36 (strofy III-V).
} 
że widząc go, zaznaje psychicznego odprężenia, że jego trud i poświęcenie miały głęboki sens. Spotkanie $z$ królem to moment spełnienia dla bohatera. W ostatnich słowach przemowy zapewnia Wojewódzki o tym, co stanowiło istotę sarmackiej strategii obrony granic, a więc i że przed wrogami nie obronią twierdze i mury, ale odwaga, męstwo oraz oddanie rycerskiego narodu. Dlatego kończąc, podwojewodzic stwierdza, że serca walczących pozostają nietknięte, chociaż mury twierdzy zostały znacznie nadwątlone.

W tym kontekście nie dziwi entuzjazm, z jakim bohater wychodził po kilkumiesięcznym oblężeniu na spotkanie króla, wypatrując z tęsknotą jego nadejścia. Twardowski, mówiąc o nim wielokrotnie w superlatywach, podaje szlachcie zachowanie Wojewódzkiego jako przykład wzorowego wypełniania obowiązków rycerskich, realizowanie z miłością zasad etosu. Postawę Wojewódzkiego można porównywać też do zachowań antycznych bohaterów epickich. Twardowski $w$ tej prezentacji nawiązuje bowiem do tradycji homerycko-wergiliańskiej.

\section{Batalistyka}

Sceny walki poprzedzone są mowami dowódców kierowanymi do żołnierzy. Wszystkie zawierają zachętę do mężnej walki, odwołują się do ideałów rycerskich. W Ekspedycyi, chyba ze względu na rozmiar utworu, autor zamieścił tylko dwie mowy. Pierwsza znajduje się w wierszu czwartym, wygłasza ją do króla kanclerz Jakub Zadzik przed wyruszeniem władcy na wojnę. Analogiczną wypowiedź we Wladystawie IV odsuwa na dalszy plan znacznie bogatsza w znaczenia mowa króla skierowana do wojska. W Ekspedycyi druga jest oracja kanclerza wygłoszona po odniesionym zwycięstwie i zawarciu pokoju polanowskiego. Autor podkreśla znaczącą rolę Zadzika zarówno podczas walki, jak też w trakcie prowadzonych rokowań:

Tak lać się krew przestała, tak Janus zamkniony,

$\mathrm{Z}$ nieśmiertelnym imieniem Pana i Korony,

W którym i ty przymierzu

Masz część, wielki kanclerzu.

Tyś nie jako Herkules łańcuchy złotymi,

Ale słowy upór ich wiązał cukrowymi,

Wieleć powinni, wiele

Sami nieprzyjaciele.

(Ekspedycyja, XV, 69-76)

Wypowiedź zawarta w wierszu szesnastym Ekspedycyi stanowi potrójny final utworu. Mowa gratulacyjna zamyka dzieło tematycznie, ponieważ podsumowuje zakończone dopiero co zmagania, obwieszcza też pokój. Autor oddaje cześć zasługom powracającego z wojny głównego bohatera i adresata. Zakończenie pod względem artystycznym ma dopełnić strukturę epinikionu pochwałą zwycięzcy, ujętą w formę gratulacji. W sensie politycznym kanclerz winszuje królowi sukcesu w imieniu całego narodu szlacheckiego z nadzieją, że ten dalej będzie dbał o dobro państwa, zapewnia zarazem o miłości poddanych, która wyrazi się w razie potrzeby czynnym udziałem całej 
braci w przyszłych zmaganiach. Miłość, odwaga i zaangażowanie poddanych zastąpią wszelkie umocnienia, jakimi dysponowali starożytni: mur Semiramidy czy tarcze Argiraspidów.

Mowa kanclerza Zadzika z Ekspedycyi, poprzedzająca wyruszenie króla na wojnę, to jakby konspekt mowy zawartej we Wtadystawie $I V$ :

Jedziesz, sarmacki Alcydo, mścić się nad zmiennymi

Krzywoprzysiężcy swymi,

Którzy nad wagę przymierza i sakrament srogi

Przepadli twoje progi.

Czym nieprzyjacioły swoje słusznie urażony,

"Siecz, pal” na wszystkie strony,

Że co dziś porożem trzęsą - karki harde zniżą

I nóg twych proch uliżą.

Niech ci błogosławią nieba i niezamierzknione

Gwiazdy świecą rodzone,

Moc zasłoni Najwyższego i strzeże z wysoka

Źrzenice twojej oka.

(Ekspedycyja, IV, 19-30)

\section{...Jedziesz nad zmiennymi}

Mścić się, polski Alcydo, poddanymi swymi,

Którzy z gruntu samego, wstyd wyzuwszy drogi,

Nad sakrament przysięgi, przepadli twe progi

I jakoby nie znali Boga być na niebie,

A drugiego na ziemi, który skarzesz — ciebie -

Ich niecnotę, do jednej złość przydawszy drugą,

To uprzędli o Tobie, że swoją tak długą

Ręką ich nie dosiężesz i ze wszytkim światem

Zwadziwszy cię około, nie będziesz mógł zatem

Odjąc się im? Czym do nich słusznie urażony,

Gniewaj się sprawiedliwie i na wszytkie strony

Siecz, pal w popiól, sięgając jako ich nadaliej,

Że wiedzą, kogo na się tak irytowali.

Sama niesprawiedliwa za tobą przyczyna

Ich pobije, i jako wiotcha pajęczyna,

Wniki się te rozsypią, które dotąd knują,

Kiedy cię tu samego nad sobą poczują.

Tak ci niech sprzyjaźliwe nieba błogosławią,

Tak stołeczni Penates i wielcy się stawią

Korony tej patroni: Stróż cię Twój zasłoni

I od ostrych krzemieni nogi Twej obroni,

Helenini obadwa nie mierzchną rodzeni,

Nie pluszczeją Plejady i wiecznej nie mieni 
Pogody Cynozura, że skoro ukrócisz

Te bestyje, szczęśliwie nazad się powrócisz.

(Wtadystaw $I V, 227$ )

Ten sam tok myślowy i podobne zwroty autor ubogaca porównaniami do sytuacji mitologicznych, pokazuje srogość rozgniewanego króla i nieuchronną zemstę. W Ekspedycyi używa Twardowski ostrzejszych określeń („krzywoprzysiężcy”; „karki harde zniżą”; „nóg twych proch uliżą”), we Wtadystawie IV tonuje nieco wypowiedź (,zmiennymi poddanymi swymi”; ,jako wiotcha pajęczyna / Wniki się te rozsypią, które dotąd knują, / Kiedy cię tu samego nad sobą poczują"). Jednak to właśnie w tym utworze Twardowskiego poseł moskiewski znalazł powód dyplomatycznej interwencji. Protesty Puszkina wywołały, jak to ujął, „....bezczeście i obelgi na cara i państwo, jak «biedna Moskwa» i inne obelżywe słowa, których wstyd pisać". Rzeczywiście, zarówno sformułowanie na temat carskich poddanych: „Niewolniczeć to bydło i ośli nikczemni” $(W t, 230)$, jak też komentarz dotyczący cara Michała, którego Twardowski miał nazwać, jak twierdził poseł, „męczycielem, trupem, albo kłodą bez duszy”, nie należą do ocen pozytywnych ${ }^{41}$.

Zbliżone budową i treścią są również komentarze odautorskie, ilustrujące reakcję zgromadzonego wojska na wypowiedź kanclerza. Żołnierze gwałtownie wyrażają chęć walki:

Rzekł — a chuć we [w]szystkich nowa zaraz się rozżarzy,

Mars im sam pojźrzy z twarzy.

Jako rozpuszczony kruszec i w miedzi cierpliwy

Wre ukrop bełkotliwy,

Tak pałają, tak Trytonom Dnieprowym głębokiem

Ponurym grożą wzrokiem.

(Ekspedycyja, IV, 31-36)

Rzekł, a z tych słów we wszytkich zaraz się rozżarzy

Serce jedno, że sam Mars jakoby im w twarzy

Pałał szczero, spod piersi wyrzuciwszy lewej

Zarzliwe Eumenidy i gorące gniewy

Im na cery. (...)

(Wtadystaw IV, 227)

Tym razem bardziej rozbudowana jest mowa z Ekspedycyi. Autor we Wladystawie IV pominął porównanie zapału wojennego do wrzącego żelaza, zastąpił też „Trytonów” „Eumenidami”. W pierwszym przypadku gniew wyraża się w ponurym wzroku, w drugim zapał wydaje się silniejszy, bo powoduje zmianę koloru twarzy. Takich reakcji nie przynosi mowa króla. Wojsko

${ }^{41} \mathrm{Na}$ wypowiedź poety poseł moskicwski zareagował żądaniem ukarania jej autora śmicrcią. Skończyło się tylko na publicznym spaleniu kart z Wladysława $I V$. Równoczcśnie palono poświęcone tematycc moskicwskicj książki Wassenberga i Gorczyna. Zob. L. Kubala, Poselstwo Puszkina w Polsce w roku 1650, w: idem, Szkice historyczne, scria I, Lwów 1898, s. 212-213, 216-217, 230-231; zob. tcż: R. Ocieczek, Sławorodne wizerunki. O wierszowanych listach dedykacyjnych $z$ XVII wieku, Katowice 1982, s. 41, przyp. 12; autorka podważa przckonanie, żc w 1650 roku spalono karty właśnie z Wtadystawa IV; S. Stalmann, op. cit., s. 136. 
wyrusza natomiast zaraz do walki, rycerze mogą więc zapał wojenny wprowadzić natychmiast w czyn. Nie jest to jednak obraz spektakularnej szarży husarskiej, walczący natrafiają bowiem na kobyliny tarasujące drogę.

Inną rangę ma mowa wygłoszona przez Jakuba Wojewódzkiego do obrońców miasta w chwili, gdy ważyły się losy obleganej twierdzy. Mówca jest jednym z walczących. Dowodzi wprawdzie oddziałami, ale musi dać przykład swoim towarzyszom. Zachęciwszy ich do dalszej obrony, sam rzuca się w wir walki. W obu utworach znajduje się też wypowiedź Wojewódzkiego, który wita króla w imieniu obrońców Smoleńska w momencie, gdy Władysław IV zaopatruje oblężone miasto czyli 10 października 1633 roku.

W Ekspedycyi nie ma mowy króla, której adresatami byliby żołnierze; jego wypowiedzi autor nie wprowadził, zapewne ze względu na to, że utwór jako pochwała skierowany był do samego władcy i to on pozostaje w każdym momencie postacią centralną, więc poeta, chyba słusznie, uznał za zbędne powtarzanie królowi jego własnej mowy do poddanych. Zaś Wtadystaw IV to historia jego czynów i panowania, zaadresowana do potomnych, dlatego wypowiedź króla ma dokumentować fakt historyczny.

Szczytowymi, najbardziej dynamicznymi fragmentami obu tekstów są relacje z walki. Ze względu na skondensowany charakter całej wypowiedzi poetyckiej dynamizm opisów zaciętości boju ujawnia się bardziej w Ekspedycyi. Sekwencje te kontrastują silnie z momentami uspokojenia akcji, kiedy autor chwali króla, opisuje rozmowy pokojowe lub przygotowanie walki. We Wladystawie $I V$... sceny batalistyczne zawierają wiele porównań, mieszczących w sobie różne skojarzenia autora, odesłania czy aluzje. Zastosowaną konwencją przypominają one opisy bitew znane z eposów pisarzy starożytnych.

W obu utworach Twardowskiego ujawnia się dramatyzm zaciętych zmagań o Skowronkowe Wzgórza. Autor opisuje moment zajęcia pod osłoną mgły i deszczu wzniesień leżących powyżej pozycji moskiewskich. Nazajutrz, gdy widoczność się poprawiła, Szein orientuje się w nowej sytuacji i rzuca do walki wszystkie siły. Wojska Rzeczpospolitej mogą też obserwować jego potęgę z góry:

...Sehin się zadziwi

I zaraz jako może wspłonąć popędliwiej

Wszytkiego się nazajutrz wyprowadzi w pole,

Gdzie, jako na odkrytym pokaże się stole,

Wielkość jego do mrówek podobna niezmiernych (...)

(Wtadystaw IV, 241).

Zwraca uwagę malarskość tego opisu ${ }^{42}$, pozwalającego widzieć czarną, skłębioną plamę, która przesuwa się błyskawicznie, budząc grozę. Twardowski wiernie oddaje manewry taktyczne Rosjan, szczegółowo rysuje ustawienie konkretnych oddziałów wroga, pokazuje moment zwarcia się obu wojsk. Komentuje następnie siłę uderzenia, ale podkreśla też fakt zaskoczenia armii królewskiej.

.... Nikdy tak ciężkiego

Razu dotąd na sobie nieprzyjacielskiego

42 Szerzej na temat malarskości i innych efektów oddziaływania na zmysły u Twardowskicgo, jak też o batalistyce, pisała Róża Fischerówna, Samuel Tuardowski jako poeta barokowy, Kraków 1931. 
Naszy nie wytrzymali i mało by beli

I góry, i tych obron już nie ustapieli,

Kiedy by Pan nie przeczul, co się działo z nimi,

I sam tumult usłyszał. (...)

(Wtadystaw IV, 242)

Walczących ratuje przed klęską przytomność umysłu władcy, który natychmiast przeformowuje zajęte manewrem taktycznym wojsko. Warto dodać, że w momencie ataku obrońcy Skowronkowych Wzgórz po nocy spędzonej w deszczu na dworze mieli właśnie zejść do obozu na posiłek i po większy zapas amunicji.

W skondensowanym opisie z Ekspedycyi widać zmienną kolej zmagań, autor pokazuje też ślepa zapamiętałość wroga i wściekłość szturmujących wzgórza. Wśród obrońców widzimy najpierw dowódców, potem króla wydającego w zawrotnym tempie rozkazy:

Tedy, co w nich rumoru, co dźwięku i siły,

Z Sehinowych ostrogów działa wraz zawyły,

Ze ślepą rezolutą ruszywszy się w głowę,

Moskwa w górę uderzy na piechotę owę,

Która, gdy ciężkim wsparta gwałtem, ustępuje.

Wydawszy się przed inne Kazimirz ratuje,

Butler po nim z Wajerem i pułk kamieniecki,

Gdzie Moczarski przywodzi, gdzie dzielny Czarnecki.

Bój krwawy, bój pamiętny, jaki drugi ledwie

U Ksantu i Termopil, gdy strony obiedwie,

Świeżych co raz posiłków sercy pobudzone,

Wściekłym gniewem czyniły ślepe i szalone.

Stąd moskiewska obłokiem z boku jezda spada,

Stąd czołgiem pochylona piechota się skrada.

Obiema silni naszy, obu, jako który

Plon, paruje Polifem $z$ Wulkanowy góry.

Pan śrzód ognia i mieczów przywodzi, szykuje,

Sam jak Argus stooki wszytko upatruje.

On, przeszedłby Fabijów sercem doświadczonych,

On, żartkością po kłosach bieżałby nietknionych.

I gdy widzi, że naszym, którzy w sprawie stali,

Szkodzi z dział nieprzyjaciel, razem się zapali

I razem: „Hej, na co się, na co dłużéj chować?” —

W głowę wojsku wszytkiemu każe następować.

Uderzą się jako grom na harde cyklopy

Wystrzelony Jowiszów, skąd krwawe zatopy,

Skąd i grady żelazne $z$ obłoków się walą,

Ziemię trzęsą i nieba ledwie nie obalą. 
W tym zgiełku i piorunach okrywa się Miński,

Kamieniecki przywodzi, czyni Madaliński,

Drzewa kruszą ogromne. A Wajer żarliwy

I Butler, i Kawaler ogień strzela żywy.

Czym z góry wsparta Moskwa da tył pochylony,

A naszy po nich, po nich, wziąwszy się w zagony,

Pole trupem położą. Aż noc nastąpiła,

Która grzbiety zelżywe płaszczem swym okryła.

(Ekspedycyja, IX, 29-64)

Mimo całej dynamiki opisu, wystarcza miejsca na odwołania mitologiczne i na uczczenie dowódców walczących formacji. Ogrom i doniosłość zmagań podkreśla rzucenie na pole walki z obu stron wszystkich sił. Twardowski stara się przybliżyć zgiełk bitwy, przedstawić ruchliwość oddziałów, oddać dramatyzm sytuacji. Można ten opis porównać do orkiestrowego crescendo, które wzmaga się w miarę dołączania nowych instrumentów do tutti, by osiągnąc w szczytowym momencie fortissimo. Decydująca walka trwa od rana do wieczora, kończy się odparciem ataku Szeina. Ostatecznie cisza zalega miejsce zmagań.

Twardowski potrafi spojrzeć na pole walki nie tylko okiem dowódcy — inżyniera wojny, ale uchwycić także doznania człowieka konającego ku chwale ojczyzny i króla:

Krew się zatym $z$ obu stron niezbrodzona leje,

Kiedy jeden drugiego na kopiją wżdzieje,

Kto w bok, kto przez obojczyk i w pół postrzelony

Albo w szwanku od koni leży porażony,

Kto jeszcze w pół żywota dopiero umiera,

Kto wnętrzności wylane po poboju zbiera,

I wspomniawszy na fanty pozostałe doma,

Płacze dokonywając. Kto z bólu zęboma

Kąsze ziemię, i żeby przestał żyć co pręcéj,

Strzał spod serca dobywa, oprócz innych więcéj

Różnych śmierci i fruktów placzorodéj wojny,

Z którego aż likworu i powodzi hojnej

Dniepr nabrzemije. (...)

(Wtadystaw IV, 243)

Ten makabryczny opis pochodzi z Wtadystawa $I V$ i wprowadza drugi biegun rzeczywistości jako antynomię wygłoszonych wcześniej mów i zachęt pod adresem mających podjąć walkę ${ }^{43}$. Poeta nie ukrywa ani zaciętości bojów, ani ich krwawego żniwa; potrafi też, zachowując stosowne konwencje opisu, przedstawić zmienne szczęście walczących. Nakreślony tu obraz lepiej przemawia do czytelnika niż ogólne „wały trupów” czy „morze krwi”. Autor potrafi oddać ból konających,

${ }^{43}$ Zob. M. Kuran, Etos sarmackiego wodza we „Wadystawie IV" Samuela Twardowskiego ze Skrzypny, w: Sarmackie theatrum oraz Wartości i slowa. Materialy z konferencji naukowej, Katowice 9-11 grudnia 1998 roku, red. R. Ocieczek, B. Mazurkowa, Katowice 2001, s. 37-54. 
którzy popełniają samobójstwa, pociętych, z rozprutymi brzuchami, plączących się we własnych wnętrznościach, zdeptanych przez konie, przebitych kopiami. To druga, mniej chwalebna strona wojny, ale staropolski epik nie boi się jej pokazać: wszak traktujący na serio ideały rycerskie muszą liczyć się z zapłatą najwyższej ceny za wierność władcy i ojczyźnie. Twardowski nie precyzuje przy tym, kto $z$ walczących umiera czy leży pocięty na miejscu walki: ten obraz jest uniwersalny jak tęsknota za domem, do którego wzdychają ofiary starć. Nie przypominają sobie króla czy Boga, ale myślą o domu, do którego nigdy nie powrócą...

Chociaż opisy makabry w literaturze baroku są zjawiskiem częstym i głęboko tkwiącym w świadomości społecznej i literackiej tamtego czasu ${ }^{44}$, a przy tym najlepiej dopełniają uroczystą wizję wojny, niewiele ich u Twardowskiego; znacznie mniej niż na przykład w późniejszym przekładzie Farsaliów Lukana autorstwa Wojciecha Stanisława Chrościńskiego (1690).

Podobnie jak inni twórcy barokowi, Twardowski potrafi wyzyskać okrucieństwo śmierci, tu akurat poniesionej podczas wojny, dla celów perswazyjnych. Jak w Wojnie domowej odnaleźć można pogardę i nienawiść do Kozaków, analogicznie w opisach zmagań smoleńskich daje się odczuć niechęć i pogardę dla Rosjan. Często powtarza się oskarżenie, że są niewolnikami i ludem barbarzyńskim. W obu tekstach Twardowski wzmacnia je, opisując losy poległego w walce Waleriana Wylezińskiego i jego towarzyszy.

Przedstawiając ich śmierć w trakcie pierwszych walk prowadzonych bezpośrednio pod dowództwem króla (zmagań o Pokrowską Górę, gdy dowódcy starali się wprowadzić do oblężonej twierdzy smoleńskiej nowe oddziały z amunicją i prowiantem), wprowadza do akcji bóstwa mitologiczne. W Ekspedycyi wspomina enigmatycznie o bezimiennej nimfie, która przyniosła zgubę głównemu bohaterowi wypadków:

Szmelinga widzę, przystojnie ubrany,

Kogo-li taka pobożność ruszyła?

Szemet podobny we krwi utarzany,

Że się Bellona nad nim użaliła.

Gniewosz z innemi srogo porzezany,

Wylezińskiego bez serca przybiła

$\mathrm{Na}$ desce nimfa. Niebo-li cierpiało,

Ze raz im umrzeć było jeszcze mało?

(Ekspedycyja, V, 81-88)

Gdy autor upamiętnia śmierć poszczególnych uczestników walk, chodzi o zgony ludzi młodych, rycerzy, którzy świadomie zachowywali reguły etosu, przedstawicieli czcigodnych, zdaniem Twardowskiego, rodzin. Marian Kaczmarek uważa, że ta wzmianka ma epitafijny charakter i że autor tak ujawnia rzeczywiste zaangażowanie emocjonalne ${ }^{45}$. Ale takie epitafium pozostaje mało czytelne. Dopiero porównanie go z Wladystawem IV czyni sytuację klarowną, zaś przynosząca straszną śmierć nimfa, a właściwie furia, zyskuje imię:

${ }^{44}$ Zob. J. Sokolski, Staropolskie zaświaty. Obraz piekla, czyśćca i nieba w renesansowej i barokowej literaturze polskiej wobec tradycii średniowiecznej, Wrocław 1994; M. Prcjs, Tajemnica arkadyjskiej groty, „Barok” 1994, nr 2, s. 85-94; J. Sokolski, Elegia "Vado mori" i jej polskie dzieje, „Pamiętnik Literacki” 1993, z. 3-4, s. 112-125.

4s Zob. M. Kaczmarek, Epicki ksztatt..., op. cit., s. 30. 
... Padnie tu ochoczych niemało,

Ale się i paniętom znaczniejszym dostało, Miedzy Szmeling którymi i Szemet podobny W pierwszej dobie zabity młodości ozdobnéj, A co więtsza i czym złość gorszą swą wydała Moskwa ku nam, że żywych w pasy popłatała Serca im wykroiwszy. Co także wielkiemu Dostało się mężowi i Wylezińskiemu, Którego na ubogiej przyplawiła desce Tetys ulitowana. (...)

$$
\text { (Wtadystaw IV, 233) }
$$

Ujawnia się też tu właśnie okrucieństwo żołnierzy Szeina wobec rannych przeciwników, którzy zostali poćwiartowani. Podobnie opisał Twardowski bezwzględność i barbarzyństwo Rosjan w Ekspedycyi, odwrócił jednak kolejność relacji. Wspomniał najpierw o wysłaniu Sołtyka po ciała zabitych, dopiero później dał ich opis:

Nietrudno Soltyk u Moskwy przehardéj

Uprasza ciała, że mu je wydadzą -

Sam by Acheron dał użýc się twardy -

Przy tym i skłaniać do miru się zdadzą.

W tym okrutniejszy nad tygry i pardy,

Że pierwej żeły i krew z nich wycadzą,

Wykroją serca (o, jak srogie czasy

Dyjomedowe!), popłatają w pasy.

(Ekspedycyja, V, 73-80)

By uzmysłowić jeszcze pełniej okrucieństwo Moskwy, we Wtadysławie IV dopełnia relację, odwołując się do znanej wówczas powszechnie mitologii:

...Znalazły tam miesce

Stajnie Dyjomedowe, Falaryjskie żłoby,

Spiżarnie Kakusowe i które podroby

Ciał ludzkich Brazylija w jatkach swych przedawa,

Tego tylko okrutnej jędzy nie dostawa,

Że ich nie żrze surowo, ale Sołtykowi

Wyda tak oprawionych. (...)

(Wadystaw IV, 233)

Do tych wymienianych jednym tchem okropności dodaje coś, co świadczy o jego wyobrażeniach na temat odkrytego ponad 150 lat wcześniej Nowego Świata ${ }^{46}$. Stawia Rosjan na równi

\footnotetext{
46 Twardowski czerpał zapewne wiadomości na temat odkryć geograficznych z gazet rękopiśmiennych - zob. K. Maliszewski, Obraz śviata i Rzeczypospolitej w polskich gazetach rękopiśmiennych z okresu póżnego baroku, Toruń 1990, s. 139-166.
} 
z ludożercami handlującymi mięsem ludzkim, bo ci w swym barbarzyństwie i dzikości — jak sądzi - zjedliby najchętniej poćwiartowane ciała zamordowanych. Jednak Rosjanie pozwalają oddziałom Rzeczypospolitej pozbierać zmasakrowane resztki zwłok.

Batalistyka w obu tekstach zajmuje zwykle kulminacyjne miejsce. Autor przedstawia zdarzenia plastycznie, dynamicznie, z rozmachem. Umie spojrzeć z dystansu na pole walki jako całość, kiedy opisuje działania dużych armii, potrafi też wydobyć szczegóły i skoncentrować się na losach czy dokonaniach wybranych osób ${ }^{47}$. Docenia wagę wypadków, bo rozstrzygnięcia dokonane w polu rzutują na dalszy los państwa i życie osobiste walczących. Twardowski nie sądzi, by wojna była najlepszym sposobem rozwiązywania wewnętrznych czy międzynarodowych problemów państwa. Chociaż traktuje ją bardzo poważnie i postrzega przez pryzmat etosu rycerskiego, jest w stanie zmienić perspektywę i spojrzeć na zdarzenia okiem śmiertelnika. Zauważa nie tylko chwałę czy klęskę szlacheckich bohaterów, ale widzi też powszechność i nieprzewidywalność śmierci. Jego żołnierze nie są też do końca bez skazy. Moga przytrafić im się niepowodzenia; armię można zmusić do odwrotu, walka bywa trudna, zaś jej przebieg i rezultat nie do przewidzenia.

\section{Od Ekspedycyi do Wtadystawa IV}

\section{Autopowtórzenia}

Płaszczyzną zewnętrznych powiązań o charakterze zdecydowanie intertekstualnym są powtórzenia zwrotów lub obrazów z innych utworów, które stanowią bądź wąsko pojmowane źródło inspiracji artystycznej (na przyklad V punkt Wladysława IV a Gestorum... Wassenberga), bądź jak najszerzej rozumiane podążanie za autorytetem twórców antycznych (Wergiliusz, Lukan) czy renesansowych, przyswojonych przez polską tradycję literacką (jak Tasso). W autopowtórzeniach sformułowań czy całych obrazów ujawnia się natomiast wewnętrzna płaszczyzna powiązań międzytekstowych, jednoczących różne utwory samego Twardowskiego bez względu na temat i formę wypowiedzi. Sięganie do własnych motywów i zwrotów na równi z dziedzictwem tradycji literackiej jest zresztą zjawiskiem specyficznym dla jego pisarstwa.

Między Ekspedycyja i Wtadystawem IV sytuuje się Książe Wiśniowiecki Jamusz. W dziele tym przedstawia Twardowski między innymi dzieje zmagań z Abazym baszą i przypomina, że tło dla działań księcia stanowiła ważniejsza i bardziej popularna wśród szlachty wojna smoleńska:

Tam wszytkich ku północy oczy obrócone,

Tam siła i armaty wszystkie wytoczone,

A jakoby tak zewsząd bezpieczne być miały,

Ledwie te Ukrainy nie nagie zostały (...)

$(K W J, 42)$.

${ }^{47}$ Zob. R. Fischerówna, op. cit., s. 86-87. 
Dzięki takiemu postawieniu sprawy łatwo autorowi zaakcentować rolę księcia Janusza w obronie wschodnich rubieży Rzeczpospolitej w sytuacji, gdy wojsko królewskie jest zaangażowane gdzie indziej, a kresowi możnowładcy zdani są wyłącznie na własne siły.

O wojnie smoleńskiej wspomina Twardowski w Księciu Wiśniowieckim... niejako przy okazji, dzięki czemu można podejrzeć warsztat pisarski wielkopolskiego poety, pojawiają się tu bowiem autopowtórzenia. Przejęcie listów Abazego do cesarza i wysłanie z tą nowiną do króla pod Smoleńsk niejakiego Wrzeszcza pozwala obserwować reakcję wojska królewskiego na wiadomość o pokonaniu Turków:

Tedy wraz po Tryjonach

Zagrzmiały w tryumfie dziala,

Grom i Echo po stronach

Z gór pobliższych się ozwała.

Zapalą ognie, uderzą do kwatrów,

Dźwięk, huk i tumult pochop weźmie $z$ wiatrów.

Porywa się strwożony

Nieprzyjaciel tą nowiną,

Razem imprezie onéj

Dziwuje się, co przyczyną?

Co jest? Czy Wołga łańcuchami spięta?

Złupiony Możajsk? Czy stolica wzięta?

(Ekspedycyja, XI 25-36)

...Piechota wyrwała,

Wprzód swe salwy: toż w duże uderzono działa,

Skąd zaweło powietrze i ziemia zadrżała.

A Moskwa gdzieś niezwykłe słysząc to strzelanie:

„O, co-li się to stało albo jeszcze stanie -

Skąd ten tryumf? Wołga-li łańcuchami spięta?

Czy-li Możajsk złupiony i stolica wzięta?”

$(K W J, 45)$

Ten sam moment przedstawił poeta również we Wtadystawie $I V$, lecz nieco inaczej ze względu na bardzo szcegółowe relacjonowanie wypadków. Twardowski zaznaczył najpierw radość strony polskiej z hołdu Tatarów. Podczas (obszernie opisywanego) fetowania tego sukcesu przybywają posłowie z nowiną o pokonaniu Abazego. Poeta podaje tylko sposób przekazania wiadomości Rosjanom. Twardowski rozszerzył więc obraz i zmodyfikował jego konstrukcję w kierunku kroniki (rezygnacja z opisu reakcji wojsk Szeina):

Ażeby się dostało Moskwie o tym wiedzieć,

Z dział jej to obozowych każe opowiedzieć.

Co gdy zadumanego przestraszy Sehina, 
Oto znowu i druga $z$ Podola nowina

Leci rączo, o świeżo zrażonym Abazie

(Wtadystaw IV, 247).

Nasuwa się ogólny wniosek, że pisząc o wojnie smoleńskiej, autor we wszystkich trzech utworach korzystał z tych samych materiałów (hipotetycznego własnego diariusza?), zgromadzonych oczywiście przed napisaniem Ekspedycyi. Twardowski uzupełnił nowymi szczególami Księcia Wiśniowieckiego Janusza, natomiast informacjami zawartymi we Wtadystawie IV dysponował już w Księciu Wiśniowieckim... (stworzonym pod koniec 1636 lub na początku 1637 roku, uzupełnionym i opublikowanym w roku 1646), gdzie zresztą przedstawił wypadki wnikliwiej niż w eposie o królu Władysławie IV. Przekonanie to potwierdza podobieństwo opisów wyprawy Wrzeszcza:

Snadź był książę, jako się prętko o tym sprawił

Umknieniu Abazinym, na podjazd wyprawił

Ratowskiego i Wrzeszcza, że gdzie by się daliej

Obrócił stąd poganin, nad nim się wieszali,

A $z$ przypadkiem na te to posłańce napadną

$\mathrm{Z}$ ramotami owymi i tak ich pokradną

W jednym cicho parowie, że już się postrzegą,

Jako $z$ nimi Harpije do swych wlot ubiegą.

Tedy posłać z tym wszytkim książęciu się zdało,

Cóżkolwiek się szczęśliwie w tej tu wojnie stało,

Tychże samych do króla, żeby to odnieśli,

Bo co by tu i przyśli, z czym nazad i ześli,

Przy tym cery i ramot owych pan zrozumiał

Humor dalszy pogański, a zaraz i umiał

Usługę tę przy drugich wdzięcznością mu swoją

Spół nagrodzić. Bo za cóż prace takie stoją,

Jeżli swojej pochwały za to zasłużonéj

Nie odniesie i wdzięku? Z czym Wrzeszcz wyprawiony

Którego nieba tedy właśnie tam przyniosły

W podsmoleńskie obozy, kiedy także posły

Chana miał tatarskiego świeżo pan u siebie,

Ofiarującego się ku jego potrzebie

Przybyć wszytką potęgą i z tamtej swéj strony

Palić Moskwę. (...)

Snadź tedy Wiśniowiecki za Dniestr beł wyprawił

Wrzeszcza z swą kompaniją, że gdzie by się bawił

I zapadł nieprzyjaciel, o nim beł wiadomy.

Aż miedzy bukowiną, w kniei gdzieś kryjomy

Przejął owe ramoty pospołu i z posły, 
I te, żeby co pręcéj pana się doniosły,

Książę zaraz pod Smoleńsk z nimi go wyprawi

I pierwszy przed innymi o tym wszytkim sprawi.

Stądże owo strzelanie ze wszytkich słyszane

Dział smoleńskich durnemu beło podejźrzane

Sehinowi. Bo i któż? Kiedy się pokłonił

Chan tatarski i wielki Turczyn sam uronił

Znacznie pierza, miał już być straszny nam i srogi?

(Wadystaw IV, 251-252)

Przedstawianie tych samych zdarzeń w kolejnych utworach nie ograniczyło inwencji twórczej Twardowskiego. Każdy ze wspomnianych tekstów posiada inny temat przewodni, któremu podporządkowany został sposób operowania szczegółami, spisanymi może w domniemanym diariuszu. W Księciu Wiśniowieckin... strukturę opowieści zdeterminowały koleje życia głównego bohatera, w Ekspedycyi materiał historyczny uporządkowała kolejność wypadków wojennych spod Smoleńska, natomiast układ Wradysław'a IV określa wspominane już dzieło Everharda Wassenberga.

Najwięcej wydaje się łączyć jednak Ekspedycyję z V punktem Wadystawa $I V$. Zmienia się wprawdzie adresat utworu, ale występują ci sami bohaterowie i wydarzenia. Przekształca się w znaczący sposób forma opisu, opowieść ulega amplifikacji, pozostaje jednak ta sama kolejność wypadków. Autor, pisząc drugi z tekstów, wyraźnie sięga do pierwszego i do innych źródeł, celem merytorycznego wzbogacenia opowieści. Zwykle postępuje tak, przedstawiając jakieśs wydarzenia mające niewiele ze sobą wspólnego, dodając im blasku porównań mitologicznych ${ }^{48}$.

\section{Ewolucja artystyczna}

Można było spodziewać się, że z upływem czasu relacja autora $z$ wydarzeń będzie bardziej zamazana i pozbawiona szczegółów. W praktyce dzieje się odwrotnie. Najbardziej skondensowana, wręcz enigmatyczna, bywa Ekspedycyja, natomiast w wierszu o Jakubie Wojewódzkim i w utworze poświęconym księciu Januszowi Wiśniowieckiemu przybywa wiadomości szczególowych. Rosnący dystans czasowy pozwala na nowe refleksje, na przesunięcie akcentów. Świadomość upływającego czasu, stopniowo topniejąca liczba uczestników zdarzeń, a więc i zacieranie się społecznej pamięci o faktach sprawia, że we Wladystavie IV Twardowski stara się maksymalnie udoskonalić relację i za punkt honoru przyjmuje przedstawienie sumy swojej wiedzy na temat wojny smoleńskiej, stara się być wiernym kronikarzem, utrwalić dla potomnych to, co godne zapamiętania. Zdaje sobie sprawę, że mogą oni zapomnieć o gwałtowności walk czy męstwie bohaterów, dlatego odsyła stale w obrazowaniu do świata mitologii, który uważa za uniwersalne i trwałe (choć nie przewidział dzisiejszej atrofii edukacji mitologicznej...) wyposażenie wykształconego społeczeństwa.

\footnotetext{
48 Konstruowanie takich odwołań ma służyć oddaniu skali zjawiska oraz nadać mu odpowiednią klasyczną rangę literacką, a przez to nobilitować. Taktyka ta wzbogaca twórczość barokowcgo epika o nową płaszczyznç naśladowania. Nie naśladuje on już tylko przyrody, ale zyskuje jako punkt odniesienia nowy, wirtualny świat antyku. Twardowski nic rezygnuje zarazem z poszukiwań przcdmiotów porównań w otaczającym go świecie natury.
} 
Przypominając potomnym imiona bohaterów, którzy postradali życie w wojnie sprawiedliwej, autor daje zarazem przykład do naśladowania — niekoniecznie zachowań szaleńczych, ale przede wszystkim wartości uniwersalnych, takich jak wierność, wytrwałość, odwaga czy umiejętność rezygnacji z własnych planów na rzecz racji wyższej. Bez wątpienia temu służy w eposie opowieść o Jakubie Wojewódzkim.

Wprawdzie niedokończony, Wtadystaw IV to chyba najdojrzałszy i zarazem najlepiej dopracowany epos historyczny Twardowskiego, do którego twórca przygotował się bardzo rzetelnie. W Wojnie domowej, kilkakrotnie rozpoczynanej w imię potrzeb chwili, wypadki wyprzedzają myśl poety. Początkowo dopracowana artystycznie opowieść przeradza się w rejestr kolejnych starć i potyczek, spis katastrof, spadających na Rzeczpospolita jedna za drugą.

Gdyby przyszło oceniać obie relacje z kampanii smoleńskiej pióra Twardowskiego z obecnego punktu widzenia, biorąc pod uwagę postrzegany bardzo subiektywnie artyzm, pierwszeństwo należałoby przyznać Ekspedycyi, ze względu na różnorodność formy wypowiedzi, jej dostosowanie do sytuacji oraz kondensację toku myśli. Gdyby zaś brać pod uwage jasność przekazu historycznego, Ekspedycyje wyprzedzilby V punkt z Whadystawa IV.

W opisach kampanii smoleńskiej determinuje Twardowskiego z jednej strony historia, z drugiej zakładany adresat utworów: odbiorca konkretny, od którego autor uzależnia stopień dokładności podawanych informacji. Im odbiorca bliższy wydarzeń, im lepiej je zna, tym mniej pisarz koncentruje się na odtwarzaniu przebiegu wypadków. Odsuwając na dalszy plan historię, skupia się na stronie artystycznej utworu i wyszukanych formach poetyckich (Ekspedycyja). Wprowadza do utworu nielicznych bohaterów, wychodząc z założenia, że czytelnik zna także inne sytuacje, porównywalne z opisami autora. Najwyższy kunszt artystyczny osiąga w tekście, w którym nie musi dbać o wierne odtworzenie szczegółów i jedynie szkicuje wydarzenia. Kierując natomiast wypowiedź do odbiorcy, który nie zna ciągu zdarzeń, Twardowski stara się mu je przybliżyć, przedstawić to, co po latach jest nieuchwytne. Dlatego we Wtadystawie IV gwałtownie przybywa bohaterów, opisy zdarzeń są bardzo szczegółowe. Nie ulega zmianie negatywne nastawienie do Rosjan. O ile jednak w Ekspedycyi więcej jest inwektyw pod adresem wojska moskiewskiego, o tyle we Wtadystawie IV negatywne oceny przeradzają się w pogardę zarówno dla moskiewskiego władcy, jak i dla „niewolniczego bydła” - ludu.

Takie traktowanie przeciwnika służy budowaniu wyraźnej opozycji aksjologicznej między atakującymi Rosjanami a wojskiem Rzeczypospolitej. Rosjanie mają kojarzyć się z tym, co w świetle etosu rycerskiego najgorsze: krzywoprzysięstwem, okrucieństwem, brakiem odwagi (walka zza umocnień, ucieczki); ogólnie rzecz ujmując z wojną niesprawiedliwą. Zachowanie polskiego rycerza ma zaś stanowić wzór dla przyszłych pokoleń. Autor nie lubuje się w makabrze opisu pobojowiska, pokazuje wyłącznie konsekwencje zaangażowania i oddania sprawie, z jakimi liczyć się muszą przyszli bohaterowie, jednak nie odwodzi ich od poświęcenia na rzecz króla i ojczyzny. Przestrzega jedynie przed okrucieństwem wojny i zaleca, by w miarę możliwości unikać rozwią- 
zywania konfliktów na drodze konfrontacji militarnej. Wypowiada w ten sposób myśli szlacheckiej społeczności, które ujawniały się w ówczesnej polityce, sprzeciwiającej się wywoływaniu jakichkolwiek konfliktów zbrojnych z sąsiadami. Według tych założeń państwo szlacheckie mogło prowadzić jedynie wojnę obronną, a więc sprawiedliwą 49 .

Punkt V Wladystawa $I V$ to swego rodzaju summa wiedzy i poglądów pisarza na temat wojny smoleńskiej i wojny wjej pierwotnym założeniu, w ogóle. Następujące po sobie jak lawina wydarzenia miały przemożny wpływ na kształt utworu. Śmierć Władysława IV, wojny kozackie, a potem potop szwedzki zmusiły autora do przedstawienia sprzecznych $z$ duchem etosu rycerskiego zachowań szlachty. Twardowski ukazał nowe spojrzenie na jej moralną kondycję w Wojnie domowej.

Jednak właśnie wizje kampanii smoleńskiej stanowią dokument: artystycznego dojrzewania twórcy, zmian zachodzących w poglądach poety na świat, i jego wspaniałej znajomości upodobań adresata poszczególnych utworów. Pozwalają też, dzięki możliwości zestawienia ich z diariuszami i pamiętnikami z tamtego okresu, zweryfikować twórczą deklarację Twardowskiego zapisaną na pierwszej stronie Wtadystawa IV: „Prawdę pisać moja jest intencyja”.

49 Por. J. Dzięgielewski, Pokój i wojna w opinii szlachty Rzeczypospolitej czasów Wladystawa IV, w: Kultura, polityka, dyplomacja. Studia ofiarowane Profesorowi Jaremie Maciszewskiemu w sześídziesiątg rocznice Jego urodzin, Warszawa 1990 , s. $131-140$. 